\author{
ROBERT STELMACH* \\ Warszawa, Polska \\ ORCID ID oooo-0002-6564-4435
}

\title{
DEFINICJA SAMOEDUKACJI RELIGIJNEJ JAKO PRZYCZYNEK DO BADAN EMPIRYCZNYCH
}

\begin{abstract}
Streszczenie: Artykuł jest próbą ustalenia podstawowych złożeń dla samoedukacji religijnej w kontekście wychowania. Przedstawiono w nim wybrane aspekty samoedukacji. Dokonano analizy obszarów poznawczych i badawczych zagadnienia. Podano definicję samoedukacji religijnej.
\end{abstract}

Słowa kluczowe: Florian Znaniecki, samowychowanie, samoedukacja, religia, pedagogika.

\section{Wprowadzenie}

Celem artykułu jest rozpoznanie procesu samoedukacji religijnej w zakresie badawczym współczesnej teologii praktycznej. Ma on charakter teoretyczny i praktyczny, gdyż z jednej strony jest próbą zdefiniowania samoedukacji religijnej, a z drugiej, stanowi materiał wyjściowy do badania empirycznego, zmierzającego do ustalenia dróg identyfikacji samoedukacji religijnej w zakresie podmiotowym i przedmiotowym.

W artykule Sylwestra Ścisłowicza (1993, s. 61-77) można znaleźć 27 definicji samokształcenia. Na pierwszym miejscu autor umieścił definicję Floriana Znanieckiego, który podaje, że jest to; „[...] dobrowolne staranie, by własną osobę upodobnić do pewnego wzoru" (Znaniecki 1972, s. 179). W samowychowaniu chrześcijańskim wzorem tym jest osoba Jezusa Chrystusa, w wyznaniach chrześcijańskich obraz ten dopełniany przedstawieniami świętych i błogosławionych, z wyjątkiem protestantów, którzy jedynie Chrystusa uważają za świętego. Podobnie ma się rzecz $\mathrm{w}$ innych religiach: $\mathrm{w}$ judaizmie jest Mojżesz i Abraham, w buddyzmie Budda, $\mathrm{w}$ islamie Mahomet itd. Drugim istotnym terminem z punktu widzenia teologii praktycznej dla samowychowania, zawartym w definicji Znanieckiego, jest „dobrowolne staranie” (1972). Sięgając do źródłosłowia określenia, można dostrzec

\footnotetext{
* Dr nauk teologicznych w zakresie teologii praktycznej Robert Stelmach; e-mail: ttks@wp.pl.
} 
z łatwością, że jego istotą jest „dobra wola”. Mamy więc do czynienia z dwiema wartościami: dobrem i wolą, wyrażającymi łącznie wolność, która jest wartością. Można $z$ tej definicji wyprowadzić cel samokształcenia religijnego, którym jest dążenie człowieka do wolności w przestrzeni wartości Dobra ${ }^{1}$. W kontekście samoedukacji religijnej Dobro ma strukturę wewnętrzną, ukonstytuowaną w osobie ludzkiej przez wiedzę i doświadczenie, głównie wiedzę religijną i doświadczenie duchowe w aspekcie indywidualnym i społecznym. Tak więc treścią samoedukacji religijnej będzie wiedza i doświadczenia duchowe, a materią indywidualny byt ludzki i społeczny, np. wspólnota religijna lub wyznaniowa ${ }^{2}$.

Znaniecki zwraca uwagę w definicji na „upodobnienie”, a nie na naśladownictwo, które nie sprzyja autorefleksji, koniecznej w samokształceniu głównie z uwagi na wartość Dobra. Naśladownictwo oddala od celu samokształcenia, jakim jest wolność polegająca na dobrowolnym wyborze wartości istotnych dla życia i bytu osoby ludzkiej. Zamyka dostęp do przestrzeni pytań możliwych i koniecznych o sens życia i znaczenie egzystencji ludzkiej jako takiej ${ }^{3}$. Termin ten wskazuje na teologiczną regułę poznania „podobieństwa i obrazu”. Stąd czynnikiem kształtującym będzie wyobraźnia ludzka i system wartości zorientowany na Dobro, które przekracza granice poznania ludzkiego, czyli duchowość. Tę można zdefiniować jako zespół jakości istotnych wartościowo w życiu duchowym człowieka. Oznacza to, że zadaniem samoedukacji religijnej może być, mówiąc w duchu wyznania prawosławnego, ratowanie człowieka, jego zbawienie, czyli m.in. dbałość o jego bezpieczne działanie i funkcjonowanie.

Dlatego właśnie celem artykułu jest przedstawienie możliwych i koniecznych warunków bytowych dla samoedukacji religijnej w postaci założeń ze względu na dobro indywidualne i społeczne w kontekście przyrodniczo-egzystencjalnym. Rozpoznanie tych warunków powinno ułatwić badania i krytykę samoedukacji religijnej na rzecz edukacji dla społeczeństwa.

Wydaje się, że w tym wypadku najłatwiej skorzystać z dorobku hermeneutyki egzystencjalnej, zaproponowanej przez Bogusława Milerskiego (1996, 2011), który podaje, choć nie wprost, wykładnię do działania badawczego, polegającą na

1 Terminy biblijne i wartości teologiczno-biblijne będą pisane $\mathrm{w}$ artykule wielką literą.

2 W tym wypadku sekty religijne zaliczam do wspólnot wyznaniowych, a nie do wyznań. W sektach dominuje określony wzorzec osobowy o charakterze duchowym, a w religiach i wyznaniach Prawda Osobowa, wyrażana w Objawieniu oraz w życiu świętych i błogosławionych, potwierdzona w Księgach Świętych i Liturgii, a nie w obrzędach. Obrzędy są wtedy rezultatem działania Prawdy Osobowej, a nie jak we wspólnotach o charakterze sekty, osnową ich działania.

3 Zauważmy, że w niektórych wspólnotach i sektach takie pytania się nie pojawiają. Sens życia i egzystencji przedstawia się w formie oferty czy też propozycji na życie, a nie w postaci poszukiwania i odnajdywania Prawdy Osobowej. Można powiedzieć, w stylu amerykańskim, że wyznawca otrzymuje gotowe ciasteczko, które wystarczy zjeść. Wypełnia ono wyłącznie funkcję leku uśmierzającego ból lęku egzystencjalnego wyznawcy, ale go nie leczy, takim lekiem jest Słowo Boże, a nie wymysł ludzki. 
osadzaniu reguł hermeneutycznych na kole teologicznym danego wyznania lub wspólnoty religijnej z zastosowaniem wnioskowania entymematycznego, poszukującego zasady współdziałania „centrum” wspólnoty wyznaniowej z „Centrum” wyznania Wiary w zakresie pedagogiki religijnej. $\mathrm{W}$ istocie realizowany jest cel twórczy: stawania się człowiekiem Wiary. Metodą realizacji tego celu jest hermeneutyka egzystencjalna i narracyjna w ramach skorelowanych części konstytutywnych procesu samoedukacji, głównie w obszarze własnej konfesji. Metoda Milerskiego otwiera działanie przestrzeni edukacji religijnej na inne systemy wartości religijnych. Dlatego może być stosowana w systemach odmiennych kręgów kultury ludzkiej.

Wiadomo jednak, że to działania duchowe decydują o tworzeniu samego siebie, a nie życie duchowe uczestników procesu edukacji religijnej. Wynika to z imperatywu twórczego człowieka, który jest rezultatem Aktu Stworzenia Świata i Człowieka. Dlatego człowiek, podobnie do świata, konstytuuje własną postać, kształtując równocześnie samego siebie. Jest to więc proces autonomiczny i naturalny, czyli zgodny z prawami natury ludzkiej i przyrody, „w wierze i przez wiarę”, nawet w nieświadomości. W tym procesie człowiek, przechodząc świadomie etapy wybranej dobrowolnie drogi, korzysta z rozpoznania Prawdy Osobowej przez jej czucie i rozumienie, które razem wzięte wyznaczają formy kształtowania osobowości i życia duchowego.

\section{Samowychowanie religijne w kontekście estetycznym}

Istotnym dla samowychowania religijnego staje się pojęcie wartości, rozumiane $\mathrm{w}$ sensie szerszym i węższym. W znaczeniu szerszym wartości stają się kategoriami filozoficznymi i teologicznymi, a w znaczeniu węższym, przyporządkowane zostają pedagogice i duchowości. Wtedy aktem wartościującym jest uczucie, a wartość stanowi o ukierunkowaniu działania podmiotu. Oznacza to, że wartość musi odwoływać się do doświadczenia, a nie wyłącznie do przedmiotu. W ten sposób stanowi warunek bytowy dla istnienia podmiotu i przedmiotu samowychowania religijnego. Wtedy sąd egzystencjalny związany z aktem wartościującym staje się przesłanką dla uczucia wartościującego. Wartość jednak nie jest tym samym, co przeżycie wartości. Tak więc uczucie wartościujące jest faktem duchowym, natomiast wartość przynależna przedmiotowi ulokowana jest w pedagogice.

Konieczne jest przy tym wyjaśnienie relacji między wychowaniem i kształceniem. Jeżeli kształcenie sprowadza się do zdobywania wiedzy i doświadczeń oraz umiejętności, to można nieopacznie uznać, że wystarczy obcować z wartościami religijnymi, żeby je wysuwać na pierwszy plan w życiu duchowym człowieka. W związku z tym trzeba pamiętać, że wychowanie estetyczne sprzyja precyzowaniu pojęcia samowychowania religijnego, gdyż jest rezultatem poglądów filozoficznych, 
ujmujących estetykę jako refleksję nie tylko nad sztuką (Ingarden 1971, 1981, 1987). Natomiast koncepcja wychowania religijnego musi pochodzić z poglądów teologicznych, ujmujących religię jako refleksję nad życiem, nad jego sensem, czy też nad jego znaczeniem. Oczywiście w kontekście pytań egzystencjalnych.

Drugie podejście oparte na kanwie wychowania estetycznego również eksploruje źródła wartości, jednak w zakresie osobowości człowieka. Wtedy wychowanie estetyczne definiuje się jako: [...] „działanie za pośrednictwem przeżyć estetycznych, jakie zawdzięczamy elementom piękna w rzeczywistości społecznej, przyrodzie i sztuce, uważając to działanie za niezbędny czynnik w całokształcie procesu wychowania pełnej osobowości człowieka" (Chmielewska 1966, s. 11). Definicja jest wyraźna i klarowna oraz odpowiada istocie procesu edukacyjnego.

Ostatecznie otrzymujemy wyróżnienie teologiczne, które koncentruje się na duchowości, a także psychologiczne, które zwraca się ku osobowości człowieka i jego życiu duchowemu. Oba pojęcia razem odwołują się do wychowania kulturowego. $\mathrm{Z}$ tego powodu konieczne jest określenie zakresu pojęcia. Ponieważ wartości są czynnikiem sprawczym zarówno dla duchowości, jak i dla osobowości, należy je odnaleźć w oddziaływaniu religijnym na człowieka, skorzystać z nich w poszukiwaniu normy poznawczej, odnoszącej się do samowychowania religijnego. W tym wypadku nośnikiem wartości jest osoba ludzka, a nie przedmiot.

Konsekwencją powyższego jest konieczność uwzględnienia determinacji sposobów życia i jego organizacji, głównie systemów wyznaniowych. Zgodnie z regułami hermeneutycznymi, należy wyznaczyć przy tym wyraźne granice. Powstaje wówczas, choć jeszcze niewyraźny, obraz zalążków ukierunkowujących działanie ludzkie, któremu towarzyszy system uczuć i emocji w zależności od miejsca i czasu ich działania. $Z$ uczuciami i emocjami wiążą się ideały i idee, zarówno jawne, jak i ukryte, które związane przez wartości wyznaczają sposoby działania członków społeczności. Uzasadniają ich działania, w pewnym wymiarze modyfikują, a nawet kontrolują. W tak przedstawionym obrazie doszukuję się tzw. centrum, w którym działają wartości, normy i standardy religijne.

Wymienione składowe, wbudowane uczuciowo, strukturalnie i funkcjonalnie, tworzą zespół wartości, wyróżniający się stopniem ich integracji. Niski stopień integracji wybranej składowej ma małe znaczenie funkcjonalne dla wiary, co nie wyklucza jego znaczenia jako historycznego wskaźnika mocnego związania $\mathrm{z}$ innymi kulturami. Wynika z tego, że jeśli odrzucimy wartości, przestajemy zajmować się sferą znaczeniową, a więc poznawczą w wyznaniach religijnych, jak i w kulturze ludzkiej postrzeganej jako całość. Można więc dostrzec, że wartości są właściwą i konieczną częścią badania religii, traktowanej jako realny fragment nie tylko życia społecznego, lecz także przyrody.

4 Zwracam przy tym uwagę na fakt, że Krytyka czystego rozumu Immanuela Kanta jest traktatem estetycznym. 
W konkluzji pragnę zwrócić uwagę na znaczenie badawcze wartości i hermeneutyki w samowychowaniu religijnym, ponieważ samowychowanie jest zdeterminowane przez środowisko organicznie, psychologicznie i społecznie. Od strony teologicznej widoczne jest niebezpieczeństwo dogmatycznego podejścia do badań, które zaprzecza hermeneutycznej regule otwartości. Hermeneutyka otwiera pola dla metodycznych badań naukowych, szczególnie ważnych dla pedagogiki religijnej, właśnie w zakresie samowychowania religijnego. W ten sposób ujawnia się możliwość prowadzenia badań przynajmniej w dwóch perspektywach poznawczych: horyzontalnym (przyrodniczym) i wertykalnym (teologicznym), co dla pedagogiki religijnej nie jest obojętne.

\section{Samodoskonalenie}

Spojrzenie na procesy samodoskonalenia człowieka z perspektywy uwarunkowań przyrodniczych i społecznych oraz religijnych nakazuje głęboką rekonstrukcję pojęcia samokształcenia. W związku z tym, że rekonstrukcja ta ma charakter jakościowy, należy więc wprowadzić inny termin. Jest nim samoedukacja. Stwarza on możliwość wyznaczenia przez jakości istotne przyrodniczo, społecznie i religijnie, nowych programów badań. Wynika to m.in. z faktu dość powszechnego, że tradycyjne sposoby porządkowania wiedzy o świecie nie potrafią udzielić zadowalających odpowiedzi na problemy współczesności, szczególnie w dziedzinie wiedzy humanistycznej i teologicznej.

Polskim badaczom i naukowcom odejście w pedagogice od starego paradygmatu pozwala rozszerzyć jej zakres badań i pozwala na budowę bardziej adekwatnego do rzeczywistości modelu teoretycznego. Jednym z jego elementów jest poszukiwanie właściwego określenia dla samokształcenia. W toku tych poszukiwań, które mają charakter jakościowy, wydaje się konieczna zmiana terminologii. Stąd pojęcie samoedukacji i w konsekwencji pojęcie samoedukacji religijnej.

Pojęcie samoedukacji religijnej, zorientowane wokół więzi kulturowych i religijnych, wyznacza szersze rozumienie aktywności religijnej i oświatowej. Już nie jest to pogląd, w którym terenem działania są wyłącznie kościoły i sale katechetyczne, lecz całokształt oddziaływań religijnych, odnoszących się do życia współczesnego człowieka. Ta okoliczność dyktuje nowe spojrzenie na więzi religijne i kulturowe oraz na rezultaty ich działania, które są znacznikami kierunków badawczych. Wypełniają one społeczny charakter samoedukacji religijnej w zakresie wcześniej przedstawionych obszarów i systemów wartości (SW). Właśnie z uwagi na osobowy i społeczny charakter samoedukacji religijnej możliwa jest do spełnienia jej rozwojowa funkcja, rozumiana nie tylko jako kontynuacja oddziaływania systemów oświatowych, lecz jako autonomiczny proces rozwojowy człowieka, od zalążków świadomości do zakończenia życia.

Stale wzrastająca rola kształcenia pozaszkolnego oraz krótszy żywot wiedzy szkolnej rodzą nowe potrzeby. Pochodzą one m.in. z konieczności stałego 
doskonalenia człowieka, co nie jest obojętne dla utrzymywania więzi religijnych i kulturowych.

W tej dziedzinie dużego znaczenia nabiera działalność kulturalna, która powinna być prowadzona w sposób metodycznie i etycznie poprawny, dająca efekty społecznie pożądane. Właśnie dzięki szerokiemu rozumieniu działalności kulturalnej można właściwie docenić wagę życia duchowego. Wynika stąd potrzeba właściwego rozumienia jej podstawowych założeń i zasad działania. Rola świadomych wpływów kulturowych wynikających z działalności religijnej i oświatowej społeczeństwa nabiera szczególnego znaczenia w dobie globalizacji społeczeństw i wejścia polskiego społeczeństwa w ekonomiczne struktury Unii Europejskiej. Powstaje więc problem zachowania i rozwoju tożsamości narodowej wyznaczonej przez określone wartości, istotne jakościowo dla społeczeństwa polskiego w przestrzeni życia duchowego. Przystępując do rozpoznania pojęcia samoedukacji religijnej, należy dostrzec czynniki warunkujące jej działanie. Można wyróżnić trzy z nich: wychowanie, samowiedza i ekspresja duchowa.

\section{Wychowanie, samowiedza i ekspresja duchowa}

Wychowanie jest tym czynnikiem, który wpływa na rozwój człowieka z zewnątrz w sposób zorganizowany (szkoła i instytucje oświatowe) i niezorganizowany (rodzina, środowisko rówieśnicze itp.). Poziom oddziaływań wychowawczych warunkuje zatem osobista możliwość doskonalenia się wychowanka. W zależności od tego, który z wymienionych sposobów oddziaływań zewnętrznych będzie lepiej przygotowywał do życia, istnieje większa możliwość przyswojenia określonego systemu wartości przez wychowanka. Wychowanie w swojej wszechstronności, tzn. we wszystkich sferach życia człowieka, jest ściśle związane z nauczaniem i przez to wspólnie z nim warunkuje przygotowanie do samodzielnego życia religijnego.

Samowiedza, zwana także w literaturze samoświadomością lub wiedzą o sobie, jest efektem samopoznania. Nie można prowadzić samowychowania bez poznania struktury własnej duchowości, tego, co zostało nabyte, doświadczone i tego, co właściwe jest tylko nam samym - tożsamości dającej nam poczucie jestestwa i samookreślenia w świecie. Chodzi tutaj także o poznanie własnej świadomości kulturowej, gdyż ona warunkuje samoedukację religijną, dopełnia nasze życie duchowe elementami kulturowymi. Pierwszym sygnałem w tym zakresie będzie uświadomienie sobie własnych upodobań religijnych i kulturowych.

Samoświadomość religijna jest zatem częścią samoświadomości w ogóle, jest wiedzą o własnym znaczeniu na rzecz odbierania i konstytuowania wartości religijnych. Wyodrębniam tutaj samoświadomość religijną od świadomości kulturowej, w tym estetycznej, która jest częścią świadomości ogólnej. Pojawia się ona w kontaktach człowieka z otoczeniem, w tzn. sytuacji estetycznej (Gołaszewska 1970, s. 580). Innymi słowy, jest to świadomość wartości religijnych, istniejących w życiu człowieka (Gołaszewska 1970, s. 15) w odniesieniu do świata zewnętrznego. 
Samowiedza wpływa na jakość samooceny i samokontroli oraz warunkuje przedsięwzięcia samowychowawcze, czyli nie tylko decyduje o pojęciu samoedukacji religijnej, ale także reguluje ten proces.

Ekspresja duchowa to trzecia jakość samoedukacji religijnej, przez którą rozumiem formę wyrażania swoich przeżyć egzystencjalnych. Przejawy ekspresji duchowej mogą być różnorodne. Począwszy od odczuwania wartości religijnych w różnych kontekstach życia własnego, a skończywszy na doświadczeniu lub tworzeniu wartości duchowych w działaniu (Pielasińska 1983, s. 32). Nie ma zatem samoedukacji religijnej bez ekspresji siebie, wzbogaconej kulturowo. Ekspresja taka uzewnętrznia się w postawach religijnych i kulturowych. Im bogatsze, bardziej wysublimowane i komunikatywne środki ekspresji, tym pełniejsza samoedukacja religijna. Ekspresja duchowa nadaje kierunek podejmowanej samoedukacji religijnej.

\section{Samoedukacja religijna}

Samoedukacja religijna jest więc aspektem samowychowania różniącym się od innych sfer, np. samowychowania moralnego czy światopoglądowego, za pomocą elementów kulturowych, co nie oznacza, że nie może ich zastąpić. Jej istota jest wspólna wszystkim dziedzinom samowychowania. Zatem o samoedukacji religijnej możemy mówić wtedy, gdy: (1) przedsięwzięcia samowychowawcze wywoływane są wyobraźnią lub wolą jednostki i są przez nią częściowo lub w pełni uświadomione; (2) dzięki wrażliwości duchowej cel i zakres przedsięwzięć samowychowawczych wytyczone są samodzielnie; (3) zadania wychowawcy i wychowanka realizuje samowychowawca w jednej osobie; (4) samowychowawca sam ustala czas, formy i metody pracy, często na zasadzie spontanicznej aktywności; (5) samowychowawca sam poznaje siebie poprzez samoanalizę i ekspresję duchowości; (6) samowychowawca sam kontroluje i ocenia siebie, swoją działalność i realizację zakładanych przedsięwzięć; (7) wpływy z zewnątrz w formie bezpośredniej i pośredniej samowychowawca interpretuje i przekłada na własną tożsamość.

Przedstawiona charakterystyka zagadnienia wskazuje, że podmiotem i przedmiotem samoedukacji religijnej jest sama osoba. Na tej podstawie można określić dwa rodzaje czynności samowychowawczych, jedne wynikają z funkcji wychowawcy, drugie z funkcji wychowanka. Do czynności wychowawcy można więc zaliczyć: (a) pobudzanie do samoedukacji; (b) stwarzanie sytuacji, w których może przejawić się ekspresja duchowości i rozwijać wyobraźnia; (c) wytyczanie kierunku rozwoju postawy religijnej; (d) wybór działań samoedukacyjnych; (e) rozpoznawanie ukrytych możliwości; (f) sprawdzanie etapowych realizacji postawionych celów; (g) interpretacja wpływów zewnętrznych bezpośrednich i pośrednich. Natomiast do czynności wychowanka można zaliczyć: (a) wyzwalanie wyobraźni i realizowanie w związku z tym własnej woli; (b) spontaniczny aktywny udział w sytuacjach ekspresyjnych; (c) określenie zadań szczegółowych w rozwoju postawy religijnej; (d) wykonywanie czynności rozwijających predyspozycje duchowe; (e) realizowanie 
doraźnych kontroli dotyczących konkretnych działań; (f) przenoszenie zinterpretowanych wpływów zewnętrznych na własną indywidualność. Wobec powyższego na podstawie analizy poglądów i badań nad samowychowaniem uważam, że definicja powinna mieć brzmienie jak niżej:

Samoedukacja religijna to autonomiczny proces wychowania oraz jego twórcza kontynuacja, integralna dziedzina samowychowania, polegająca na samodzielnym kreowaniu własnej postawy religijnej w oparciu o jakości i wartości religijne ulokowane w rzeczywistości społecznej odnoszące się do: państwa, obyczajowości, wiedzy, moralności oraz przyrody i sztuki, w obszarze duchowości i życia duchowego ${ }^{5}$.

Poszczególne części przytoczonej definicji wymagają szerszego wyjaśnienia.

Wynika z niej, że samoedukacja religijna rozpoczyna się w rodzinie, a kończy się na „łożu śmierci”. Potraktowanie samoedukacji religijnej jako kontynuacji wychowania współczesnego człowieka świadczy o tym, że jest ona częścią systemu kształcenia. Wskazuje także, że nie jest to indywidualna sprawa osoby, która ją uprawia, gdyż ma wpływ na szerszy kontekst pedagogiczny i społeczny. O tym, że jest to kontynuacja twórcza, świadczy chociażby pojawienie się nowego podmiotu wychowawczego, który nie tylko uzupełnia braki wychowania, ale je wzbogaca przez rozszerzanie lub pogłębianie, bardzo często dzięki zastosowaniu oryginalnych metod i środków, właściwych postawie religijnej i kulturowej.

Ukazanie samoedukacji religijnej jako integralnej dziedziny samowychowania akcentuje powiązania $\mathrm{z}$ innymi dziedzinami samowychowania, takimi jak światopoglądowe i moralne. Nie da się ich w sposób wyraźny oddzielić od siebie, ponieważ składają się one na treść procesu samowychowania. W samoedukacji religijnej można znaleźć pierwiastki innych dziedzin samowychowania.

W wychowaniu wychowawca kieruje, kształtuje osobowość i duchowość wychowanka. W samowychowaniu rolę wychowawcy przejmuje samowychowawca, który kieruje samym sobą. Głównie w tym aspekcie uwidacznia się samodzielność samowychowawcy, tzn. przy ustalaniu kierunku samoedukacji i określeniu przedsięwzięć samoedukacyjnych. Wywołuje je bowiem wyobraźnia i ekspresja duchowości, co wzajemnie się napędza. Samodzielność uwidacznia się również w czynnościach realizacyjnych samoedukacji. Wszelka płynąca pomoc $\mathrm{w}$ formie porad czy propozycji, jeśli zostanie przyjęta przez samowychowawcę, nacechowana jest jego indywidualnością, ponieważ odwołuje się do jego tożsamości. Natomiast bodźce zewnętrzne, inspirujące samowychowawcę do określonego działania, zostają przez niego przetworzone i wprowadzone do realizacji celów samoedukacji. W tym także wyraża się aspekt samodzielności.

5 Zob. Ludwiczak 2009. Równocześnie pragnę zwrócić uwagę na rozróżnienie pojęcia „życia duchowego” od pojęcia „duchowości”. 
Jeżeli używa się terminu „kreowanie” w stosunku do osobowości i duchowości, to oznacza się nim sferę działań samoedukacyjnych między celem i modelem osobowym, który powodowany jest wolą lub wyobraźnią, oraz elementami, które należy w związku z tym przeobrazić, przekształcić w sobie, tak aby uzyskać pożądany obraz samego siebie.

Przedmiotem, który w samoedukacji religijnej ma ulec przekształceniu, jest postawa religijna. Składają się na nią trzy podstawowe elementy: intelektualny, uczuciowy i realizacyjny. O nich z kolei decydują spontaniczne komponenty, stanowiące strukturę, kompozycję postawy religijnej, w zależności od jej przedmiotu. Materiałem, który jest przetwarzany, są jakości i wartości religijno-kulturowe rzeczywistości społecznej, przyrody i sztuki, odczuwane przez samowychowawcę, podlegające jego osobistej interpretacji, które są przenoszone na siebie i własne życie.

Przez wartość religijną rozumiem szczególną własność przysługującą nie tylko przedmiotom, lecz także zjawiskom przynależnym do świata człowieka i przyrody. $\mathrm{Na}$ wartość religijną składają się poszczególne elementy, które określiłem mianem jakości religijnych ${ }^{6}$. Jakość religijna, podobnie jak kulturowa, może występować niezależnie, niejako samoistnie, ale też niektórym wytworom człowieka i przyrody, choć też są estetyczne, nie jest przyporządkowana wartość religijna. Treść sformułowanej definicji ujawnia potrzebę określenia celu nadrzędnego samoedukacji religijnej oraz jej zakresu drogą sprecyzowania treści i zadań samoedukacji religijnej lub odpowiedniego ujęcia metodologicznego.

\section{Treść i zadania samoedukacji religijnej}

Za nadrzędny cel samoedukacji religijnej uważam alternację jakości i wartości kulturowych rzeczywistości społecznej, przyrody i sztuki na siebie i własne życie duchowe. W tym wypadku alternację rozumiem jako „przystosowanie” jakości do wartości zawsze i tylko wtedy, gdy wartość posiada każdą własność jakości wedle ich wzajemnego stosunku, przysługującą tejże jakości ${ }^{7}$. Tak postawiony cel wyraża zarówno adaptacyjną, jak i rekonstrukcyjną funkcję samoedukacji. Adaptacyjną, ponieważ elementy religijne świata natury ${ }^{8}$ i człowieka są odczuwane przez osobę. W ten sposób następuje swoiste porozumienie $\mathrm{z}$ zastanym światem wartości religijnych. Natomiast funkcja rekonstrukcyjna wyraża się w przekształcaniu wspomnianych elementów na siebie i własne życie duchowe. Aby nadrzędny

6 Główną jakością jest duchowość. Wartość jest własnością złożoną z jakości. Na przykład na wartość estetyczną jak „wzniosłość” w dziele malarskim składać się mogą odpowiednio skomponowane główne jakości estetyczne: barwa i kształt.

7 Zastosowałem tu rodzaj definicji genetycznej, ale nie o charakterze źródłowym, lecz w zakresie funkcjonalnym (działania), opartym na dziedziczeniu, które jest tu jej warunkiem bytowym. Zastosowanie tej formy ma ogromne znaczenie badawcze i poznawcze, które można rozwinąć na podstawie rezultatów badań empirycznych.

8 Na przykład Święta Góra, święty krater, święte drzewo, święta woda [woda święcona]. 
cel samoedukacji religijnej mógł być zrealizowany, spełnione muszą być cele pośrednie, które dalej będę nazywał zadaniami samoedukacji religijnej.

Wskazać tu należy na cztery typy zadań realizowanych w procesie samoedukacji religijnej: (1) samodzielne rozwijanie wrażliwości duchowej na podstawie jakości i wartości rzeczywistości społecznej, przyrody i sztuki; (2) samodzielne kształtowanie życia religijnego w wymiarze społecznym, w kontaktach z przyrodą i sztuką; (3) rozwijanie aktywności twórczej, których cel zorientowany jest na (4) wzbogacanie doświadczeń religijnych. Na podstawie wymienionych typów zadań skonstruuję procedurę badawczą i poznawczą, która wyodrębni w sposób wyraźny typy samowychowawców religijnych. Potrzebne tu będą przynajmniej dwie techniki badacze i przynajmniej dwa podejścia metodologiczne, uwzględniające dwa wymiary ludzkiej egzystencji, przyrodniczy i duchowy.

\section{Wrażliwość duchowa}

Wrażliwość duchowa to taki mechanizm wewnętrzny, który warunkuje jakość i poziom samowychowania religijnego. Jest ona związana zarówno z wrażliwością uczuciową, jak i moralno-społeczną. Warunkuje percepcję kulturową i twórczość. To taka sfera istoty natury bytowej człowieka, która świadczy o naszej indywidualności. Można patrzeć i nie widzieć, można słuchać i nie słyszeć - reguluje ona poziom naszej duchowości. Im czulsza wrażliwość, tym więcej dostrzegamy, słyszymy i czujemy. Wzmaga się ciekawość i chęć poznania świata i człowieka oraz ich natury w różnorodnych przejawach bytu i egzystencji. Wrażliwość duchowa jest zmienna, co oznacza, że niekształcona może zanikać, podobnie jak symboles. Z tego też wypływa sformułowane zadanie dążenia człowieka do coraz bogatszego poznania świata i siebie samego. Zadanie to zmierza do podnoszenia poziomu wartości życia codziennego i jakości życia duchowego.

Kształtowanie kultury w zakresie życia religijnego dotyczy kształtowania środowiska, nawyków i przyzwyczajeń kulturalnych, kultury pracy, kulturalnej zabawy, obyczajów i obrzędów, stosunków międzyludzkich, kultury erotycznej, żywego słowa i innych dziedzin aktywności człowieka. W zakresie kontaktów z przyrodą kształtowanie czynnego stosunku do otoczenia poprzez sport, turystykę i inne formy rekreacji na jej tle, ochronę środowiska naturalnego, pielęgnację roślin i zwierząt, dbanie o zieleń i kwiaty w środowisku oraz wnoszenie elementów piękna

9 Podobnie ma się rzecz z symbolami. „Akt tworzący symbol jest aktem społecznym”, twierdzi Paul Johannes Tillich (1959-1975, s. 197), cytat za: Milerski 1996, s. 92. „Dlatego też symboli nie da się wymyślić, one rodzą się i umierają. Pojawiają się, gdy dojrzewa do nich duchowa sytuacja i umierają, gdy ta sytuacja ulega zmianie”. Również tenże (1987, s. 63) zauważa: „Symbole nie pojawiają się dlatego, że ludzie ich usilnie pragną, ani nie umierają z powodu krytyki naukowej bądź praktycznej. Znikają dlatego, że nie wywołują już odzewu w zbiorowości, w której obrębie znalazły swój pierwotny wyraz". 
przyrody do własnego środowiska. W zakresie kontaktów z wiedzą kształtowanie pogłębionego postrzegania dzieł ludzkiego umysłu i rąk, dającego indywidualną wiedzę o świecie i życiu, kształtowania doboru wartości, upodobań religijnych, polegającego nie tylko na ocenie, ale także na aktywnym odnoszeniu się do wiedzy czy też wartości religijnych rzeczywistości społecznej i przyrody. Przedsięwzięcia w tych zakresach wypływają z potrzeby godnego, religijnego i kulturalnego życia człowieka.

Zasadniczą kwestią w badaniu wrażliwości duchowej jest umiejętność rozróżniania życia duchowego od duchowości. W związku z tym mamy do czynienia $\mathrm{z}$ dwoma podejściami do rzeczy. Pierwsze podejście ma charakter psychologiczny i dotyczy życia duchowego człowieka. Drugie -teologiczne - zajmuje się duchowością osoby ludzkiej. Wynikają z tego konsekwencje metodologiczne. Wydaje się, że $\mathrm{w}$ badaniu najbardziej skuteczna będzie metoda hermeneutyczna w zastosowaniu technicznym zaproponowanym przez Milerskiego (2011). Zastosowanie metodologii B. Milerskiego rozstrzyga zasadniczą kwestę postępowania badawczego, ponieważ wymaga wyboru analizy czynnikowej. Wybór na tym etapie może mieć charakter intuicyjny, jednak można go już uznać ze względu na podmiot i przedmiot badania, który odwołuje się do prawdy osobowej (nie mylić z prawdą osobistą). Równocześnie włącza do badań konteksty działania wyznaczonych operatorów $\mathrm{w}$ definicji samoedukacji religijnej: form i metod samowychowania religijnego, etapów, charakterystyki samowychowawców religijnych oraz czynników wpływających na samowychowanie religijne i kształtowanie postawy religijnej. $\mathrm{W}$ takich okolicznościach należy odrzucić działanie przypadku w samoedukacji religijnej ze względu na świadomy wybór i kryterium prawdy osobowej. Zmienne losowe wykorzystuje się głównie w badaniach ilościowych, a tu mamy do czynienia $\mathrm{z}$ badaniami jakościowymi i jakościowo-ilościowymi, ze względu na podmiot badania i kontekst jego egzystencji, którym jest on sam i jego duchowość. Właśnie z tego powodu kierunek badań wyznacza w takim ujęciu rzeczy hermeneutyka egzystencjalna i narracyjna, w których najmocniej respektowane jest działanie Słowa w każdym wymiarze.

\section{Rozwijanie aktywności twórczej}

To zadanie zmierza, na podstawie realnej oceny własnych sił twórczych, do realizowania zamierzeń i celów wypływających z wyobraźni. Nie ma aktywności twórczej, jeżeli występuje jakakolwiek forma przymusu. Ten rodzaj aktywności cechuje tylko myślenie i działanie samodzielne. Przedsięwzięcia tej natury biorą się z tego, że każdy dostrzega świat indywidualnie, przez pryzmat samego siebie. W tym tkwi źródło twórczości, która zaczyna się wtedy, gdy nastąpi chęć wyrażenia własnej interpretacji rzeczywistości, drogą odpowiednich środków i czynności, aż do pełnego jej skrystalizowania. Twórczość przejawiać się może w pomysłach, inspiracjach, działaniach, postawie wobec świata, rozwijaniu własnej osobowości 
i duchowości. Poza twórczością, formami aktywności twórczej są odkrycia - odnajdywanie rzeczy istniejących oraz inwencje - wynajdywanie rzeczy nowych (Gloton, Clero 1985). Rozwijanie aktywności twórczej pozwala na wytworzenie własnej wizji przyszłości, niekoniecznie opartej na dotychczasowych doświadczeniach (Obuchowski 1985, s. 151).

Dzięki aktywności twórczej doskonalimy własne czynności twórcze, formy i metody samowychowania, rewidujemy cele i stawiamy sobie wyższe wymagania, stajemy się bardziej odpowiedzialni za siebie i efekty własnej działalności. Przedsięwzięcie tego typu zmierza do porozumienia z innymi ludźmi, jednoczenia się we wspólnocie religijnej poprzez przeżywanie wartości duchowych rzeczywistości społecznej i twórczości. Możliwości rozwoju aktywności twórczej należy więc badać w kontekście samooceny i samokontroli w ujęciu wartości dobra, prawdy i piękna, które wyznaczają jego kierunki.

\section{Konkluzja}

Podkreślić należy brak pogłębionej refleksji teoretycznej dotyczącej samego definiowania terminu samowychowania religijnego i określenia problematyki tego zjawiska. W związku z tym podjąłem próbę własnego sformułowania pojęcia, problematyki i znaczenia samowychowania religijnego, w szerszym procesie samokształcenia i kształcenia ustawicznego. Zawarte w artykule ustalenia traktuję jako teoretyczno-metodologiczne założenia własnego badania empirycznego. Zmierza ono do weryfikacji przyjętych założeń i hipotez teoretycznych. Dotyczą one metodologii, form i metod samowychowania religijnego, etapów samowychowania, charakterystyki samowychowawców religijnych oraz czynników wpływających na samowychowanie religijne i kształtowanie postawy religijnej. Artykuł ma charakter otwarty, ponieważ sprawa samoedukacji religijnej jest otwarta. W ten sposób autor zaprasza osoby zainteresowane do dyskusji nie tylko w jego przedmiotowym zakresie.

\section{Bibliografia}

Baley S. (1946). Drogi samopoznania. Kraków: Wiedza. Zawód. Kultura.

Bergson H. (1957). Ewolucja twórcza, tłum. Znaniecki F. Warszawa: Książka i Wiedza.

Chmielewska A. (1966). Problemy wychowania estetycznego. W: O wychowaniu estetycznym w szkole podstawowej, praca zbiorowa Słońska I. (red.). Warszawa: Nasza Księgarnia.

Dąbrowski K. (1975). Osobowość i jej ksztatcenie przez dezintegrację pozytywną.Warszawa: Polskie Towarzystwo Higieny Psychicznej.

Dewey J. (1975). Sztuka jako doświadczenie, tłum. Potocki A. Wrocław-Warszawa-KrakówGdańsk: Zakład Narodowy im. Ossolińskich.

Fromm E. (1970). Ucieczka od wolności, tłum. Ziemilscy O., A. Warszawa: Czytelnik. 
Gloton R., Clero C. (1988). Twórcza aktywność dziecka, Wojnar I. (tłum.). Warszawa: Wydawnictwa Szkolne i Pedagogiczne.

Gołaszewska M. (1970). Świadomość piękna. Warszawa: Wydawnictwo Naukowe PWN. Gołaszewska M.(1984). Estetyka rzeczywistości. Warszawa: Instytut Wydawniczy Pax. Gołaszewska M. (1986). Kim jest artysta. Warszawa: Wydawnictwa Szkolne i Pedagogiczne. Ingarden R. (1971). U podstaw teorii poznania. Cz. 1. Warszawa: Wydawnictwo Naukowe PWN.

Ingarden R. (1972). Książeczka o człowieku. Kraków: Wydawnictwo Literackie.

Ingarden R. (1981a). Spór o istnienie świata. Warszawa: Wydawnictwo Naukowe PWN.

Ingarden R. (1981b). Wykłady i dyskusje z estetyki. Warszawa: Wydawnictwo Naukowe PWN.

Jeżowski J. (1959). Piętnaście prawideł postępowania dla młodzi należącej do Zgromadzenia Przyjaciót Pożytecznej Zabawy. W: Wybór pism filomatów. Konspiracje studenckie $w$ Wilnie 1817-1823. Witkowska A. (oprac.). Wrocław: Zakład Narodowy im.Ossolińskich. Jundziłł I. (1975). O samowychowaniu: podręcznik dla młodzieży. Warszawa: Nasza Księgarnia.

Kozakiewicz M. (1975). Każdy wybiera sam siebie. Warszawa: Ludowa SpółdzielniWydawnicza. Krawczyk Z. (1975). Wprowadzenie do kultury plastycznej - kształtowanie percepcji. Warszawa: Wydawnictwo Naukowe PWN.

Kuhn T. (1968). Struktura rewolucji naukowych, tłum. Stefan Amsterdamski. Warszawa: Wydawnictwo Naukowe PWN.

Ludwiczak S. (1969). Samokształcenie w wojsku. Warszawa: Wydawnictwo MON.

Ludwiczak S. (1978). Działalność kulturalna w kształceniu dorosłych. Warszawa: Instytut Wydawniczy CRZZ

Ludwiczak S. (2009). Samoedukacja. Warszawa: Mado s.c. Wydawnictwo. Bąkowscy D.K. Milerski B. (1996). Z problemów hermeneutyki protestanckiej. Łódź: Wydawnictwo Ewangelickie św. Mateusza.

Milerski B. (2011). Hermeneutyka pedagogiczna. Warszawa: Wydawnictwo Naukowe Chrześcijańskiej Akademii Teologicznej.

Obuchowski K. (1985). Adaptacja twórcza, Warszawa: Książka i Wiedza.

Obuchowski K. (1986). Dostojeństwo namiętności, czyli Rollo May nazywa swojego dajmoniona.,Literatura”, nr 7-8 (46).

Okiński W. (1935). Procesy samokształceniowe: próba ustalenia pojęcia samokształcenia ze stanowiska socjologii. Poznań: Dom Książki Polskiej.

Pacek S. (1977). Samowychowanie studentów. Warunki i efekty. Warszawa: Wydawnictwo Naukowe PWN.

Pielasińska W. (1983). Ekspresja - jej wartość i potrzeba. Warszawa: Wydawnictwa Szkolne i Pedagogiczne.

Pierwsza Ogólnopolska Konferencja Oświatowa w sprawach Samokształcenia (1946). Warszawa:Wydawnictwo Centralnej Poradni Samokształcenia.

Read H. (1976). Wychowanie przez sztukę, tłum. Trojanowska-Kaczmarska A. WrocławWarszawa-Kraków-Gdańsk: Zakład Narodowy im. Ossolińskich. 
Rudniański J. (1984). Człowiek i sztuka. Warszawa: Instytut Wydawniczy Związków Zawodowych.

Ruskin J. (1977). Sztuka. Społeczeństwo. Wychowanie, tłum. Doroszowa Z., Treter-

Horowitzowa M. Wrocław-Warszawa-Kraków-Gdańsk: Zakład Narodowy im.

Ossolińskich.

Schleiermacher F. (1995). Mowy o religii: do wykształconych spośród tych, którzy niągardza, tłum. Jerzy Prokopiuk. Kraków: Wydawnictwo „Znak”.

Skrzypczak H. (1986). Organizacja i metody samokształcenia. W: Poradnik metodyczny dopracy samokształceniowej. Warszawa: Wydawnictwa Szkolne i Pedagogiczne.

Stanisławski Konstantin S. (2010). Praca aktora nad sobą. Kraków: Wydawnictwo Akademii Sztuk Teatralnych.

Szczepański J. (1986). Zapytaj samego siebie. Warszawa: Nasza Księgarnia.

Szewczuk W. (1962). Psychologia człowieka dorosłego. Warszawa: Wiedza Powszechna.

Ścisłowicz S. (1993). Z dziejów samokształcenia w Polsce i na świecie do połowy XX wieku.

„Toruńskie Studia Dydaktyczne”, nr 3 (11).

Tillich P.J. (1959-1975). Gesammele Werke. T. 5. Sttudgart: Kunstbuch.

Tillich. (1987). Dynamika wiary, tłum. Adam Szostkiewicz. Poznań: Wydawnictwo „W drodze”.

Turos L. (1975). Andragogika. Warszawa: Wydawnictwo Naukowe PWN.

Urbańczyk F. (1965). Dydaktyka dorosłych. Wrocław: Ossolineum.

Włodarski Z. (1985). Rozwój i kształtowanie doświadczenia indywidualnego. Warszawa,

Wydawnictwa Szkolne i Pedagogiczne.

Wojnar I. (1975). Wstęp. W: Dewey J., Sztuka jako doświadczenie. Wrocław-Warszawa-

Kraków-Gdańsk. Zakład Narodowy im. Ossolińskich

Wojnar I. (1980). Teoria wychowania estetycznego - zarys problematyki. Warszawa: Wydawnictwo Naukowe PWN.

Wroczyński R. (1965). Praca oświatowa. Warszawa: Nasza Księgarnia.

Wroczyński R. (1973). Edukacja permanentna. Problemy - perspektywy. Warszawa:

Wydawnictwo Naukowe PWN.

Znaniecki F. (1973). Socjologia wychowania. Warszawa: Wydawnictwo Naukowe PWN.

\title{
THE DEFINITION OF RELIGIOUS SELF-EDUCATION AS A CONTRIBUTION TO EMPIRICAL RESEARCH
}

\begin{abstract}
The article is an attempt to establish the basic elements for religious self-education in the context of upbringing. It presents selected aspects of self-education. The cognitive and research areas of the issue were analyzed. A definition of religious self-education is given.
\end{abstract}

Keywords: Florian Znaniecki, self-upbringing, self-education, religion, pedagogy. 